\title{
Implementation of Teaching Model of Jurisprudential Inquiry Analysis as Prevention Effort from Hoax Among Students
}

\author{
Dadang Sundawa*, Susan Fitriasari, Dede Iswandi, Dwi Iman Muthaqin \\ Civic Education \\ Universitas Pendidikan Indonesia \\ Bandung, Indonesia \\ *d_sundawa@upi.edu
}

\begin{abstract}
Information technology is one factor that can change society, because its existence can have negative impacts such as the emergence of hoaxes in the community. The impact of the hoax is very dangerous, such as conflicts between individuals to conflicts between groups. In line with educational goals that want to create a knowledgeable and characteristic human, with the creation of a knowledgeable and critical man, is expected to avoid the dangerous hoax that spread in the community. This study of learning innovation entitled Implementation Learning Model Jurisprudential Inquiry Analysis As Prevention Efforts Hoax News among students. In this research, the researcher tries to introduce Jurisprudential Inquiry model of learning, a model that can improve the mindset of students to have critical thinking so as to analyze the social phenomena found in the community, related to the phenomenon of hoax so this research find out how effective the model Jurisprudential Inquiry learning can influence students' thinking in analyzing the truth of news in society.
\end{abstract}

Keywords—hoax news; jurisprudential inquiry; learning innovations

\section{INTRODUCTION}

Indonesia is a constitutional state (Article 1 Paragraph (3) of the Constitution of the Republic of Indonesia Year 1945) which has the authority to regulate and protect its citizens, including in terms of freedom of thought and expression [1]. Freedom of opinion is also guaranteed its rights with Law No. 9 of 1998 on Freedom of Expression of Public Opinion [2]. However, over the times and technology, freedom of speech is done through media that not only cover print media and broadcast media only, but also through online media / internet / social media that become very crowded with news and share information that either hoax or not, hate crime (cyberhate), and increasing cyber-bullying $[3,4]$. This state of affairs asserts that the information technology has a negative impact that can harm many parties due to unclear laws governing the use of information technology, such as crimes in the world of telematics (cybercrime), violations of intellectual property rights in cyberspace and others and weak rules on the guarantee of security and confidentiality of information in the utilization of information technology. Finally, the information is able to lead user interpretation (user) in accordance with the expected by people who have interests in it $[5,6]$.

This is reinforced by the results of research that says that the spread of hoax in Indonesian social media entered a phase that is quite worrisome, because it has a serious impact on the social life of citizens. Friendship broke up, the family was not harmonious, even horizontal conflicts had occurred when there were some residents who were consumed by the news hoax [7]. Hoax itself is understood as an attempt to deceive or outsmart the reader / listener to believe something, when the creator of the fake news knows that the news is false. Hoax aims to create public opinion, lead public opinion, form a perception also for hufing fun that examines the intelligence and accuracy of Internet users and social media. The purpose of the spread of hoax is diverse but in general the hoax is spread as a joke or just a fad, dropping a competitor (black campaign), promotion with fraud, or an invitation to do good deeds that actually have no clear argument in it. However, this caused many hoaxes hooked to immediately spread to colleagues so that eventually this hoax quickly spread [8]. Hoax is considered troubling because it is a false story used to attract mass opinion for material interests. Type of information hoax shaped pictures, photos, videos, cartoons, and news. Sources of research data are books and websites related to media, Islamic communication, hoax development from time to time [5].

Therefore, hoaxes should be identified to avoid further misunderstandings that could have significant impacts and negative impacts through different hoax detection by definition [9-12]. One effort to prevent negative impact from hoax news is through education. Just as in Higher Education prevention of hoax news can be anticipated by revitalizing the course. Students should be able to think critically of all hoax news. To develop the critical thinking of the students especially in anticipating the hoax news needs to be innovative learning model in the lecture so that it can anticipate the negative impact of the news hoax spread. One of the innovative models of Jurisprudential Inquiry Model (Jurisprudential Inquiry Model).

Jurisprudential Inquiry Model (Jurisprudential Inquiry Model) model is a learning model that can be said is still new. This learning model has not been known by many educators, especially lecturers. The Jurisprudential Study Model was 
spearheaded by Donal Oliver and James P Shaver. This model of learning is based on the understanding of society that everyone different views and priorities of each other, and social values are related to each other. This model emphasizes that everyone can give an opinion on issues that develop in the community. These issues are brought into class and then discussed by students in the classroom. Issues that are very close to the life of the students can encourage to speak up to express their opinions, where students are required to dare to speak their opinions, where students are also required to find a problem related to issues that develop in the community [13]. This is reinforced by another view that prevention of the flow of hoax information can be made by increasing community literacy through the active role of government, community leaders and communities, providing easy access to the correct source of information on every hoax issue, systematic and sustainable education and action an effective law for its spreading [8].

Based on the above background, it is necessary to make a study on the innovation of learning models and Implementation Learning Model Analysis Jurisprudential Inquiry As Prevention Efforts News hoax In Student. The research was conducted in Introduction to Indonesian Law course aimed at improving the critical thinking of students of the Department of Citizenship Education, Faculty of Social Sciences Education, Universitas Pendidikan Indonesia.

\section{METHOD}

The research activity of innovation of this learning model was conducted on Introduction to Indonesian Law, Department of Citizenship Education, Faculty of Social Science Education, University of Indonesia Education, which was conducted starting April 2017. The research method used was quasi experimental method. Selection of this method is adjusted to the purpose of research, namely to test the benefits of application of jurisprudential inquiry-based learning model in overcoming student learning difficulties in the course Introduction to Indonesian law. The subject of research in this study is the 2nd semester students of the Department of Citizenship Education who attended Introduction to Indonesian Law (PHI) with a total of 98 students.

Data collection techniques used in this study include: (1) observation of participation/observation (2) study documentation; (3) Focus Group Discussion; and (4) questionnaires. Data collection activities using techniques according to the type of instrument used as follows: Participatory observation, conducted by researchers as observers by involving themselves in lectures Introduction to Indonesian Law is being done. The data collected through observation is obtained through learning resources from students and lecturers. Documentation study, used to capture data in written documents indicating a connection with contextual learning problems jurisprudential inquiry based. Questionnaires are distributed to students to see their perceptions of the application of the jurisprudential inquiry model and its impact is that students can think critically in dealing with the hoax news circulating in the community.
This research is conducted to know the extent to which the Learning Model jurisprudential inquiry can be applied in the course of Introduction to Indonesian Law. In the Introduction to Indonesian Law, students will be given cases in the form of social issues that exist in the community. Students will analyze in depth on these issues and be associated with legal theories and legislation, hopefully students will be able to provide an indepth analysis of the case.

\section{RESULT AND DISCUSSION}

The implementation of the jurisprudetial inquiry model is done in the introductory course of Indonesian Law followed by 98 students divided into two classes. Lecture activities using Jurisprudential Inquiry Learning at lectures are conducted not only in class or outside the classroom with a democratic, participatory and fun atmosphere. This is done in upholding the value of sustainability to increase students' constitutional awareness. The lecturing method used in 16 meetings is held a discussion in normative and analytical so that the results of the discussion obtained to be input and reference materials of knowledge to be transmitted back to the community later. The series of lectures Introduction to Law.

Cooperative Learning, conducted through group discussion, presentation of papers, and group presentations. The stages are (1) the group is divided into 10 groups consisting of 4-5 members; (2) each group has environmental jargon; (2) each group creates and presents a paper based on a predetermined environmental issue theme; (3) create an interesting presentation presentation using PowerPoint and mind map.

Bring legal lecturers and conduct Focus Group Discussion. The stages are: (1) the expert lecturer is divided into lecturer of civil law expert, constitutional law lecturer, and lecturer of environmental expert; (2) expert lecturers who are submitted to convey some material about legal products related to the environment and effective law enforcement; and (3) sharing and reflection roses are conducted to develop students' constitutional awareness.

Measurement of the effectiveness of learning model jurisprudential inquiry in lectures, conducted by distributing questionnaires distributed to 98 students, the system of questionnaire dissemination is done electronically so as to minimize errors in the calculation and processing of data, and questionnaire analysis conducted on student Citizenship Education 2016 amounted to 98 Students.

The general description of the results of data processing through a questionnaire about the learning model and the media used:

TABLE I. THE RESULTS OF DATA PROCESSING THROUGH A QUESTIONNAIRE ABOUT THE LEARNING MODEL AND THE MEDIA USED

\begin{tabular}{|l|l|l|l|l|}
\hline $\begin{array}{c}\text { Count of } \\
\text { Timestamp }\end{array}$ & \multicolumn{4}{c|}{ Column Labels } \\
\hline Row Labels & Good & Very Well & Enough & Grand Total \\
\hline Good & 7 & 21 & 5 & 33 \\
\hline Very Well & 22 & 37 & 2 & 61 \\
\hline Enough & 1 & 2 & & 3 \\
\hline Less & 1 & & & 1 \\
\hline Grand Total & 31 & 60 & 7 & 98 \\
\hline
\end{tabular}


From the results of the data Table I collection can be described student perception that the learning model Jurisprudential Inquiry material taught more easily understood, when applied in the class as much as $62.2 \%$ or most students stated that the model of Jurisprudential Inquiry analysis analysis one interesting model. As much as $59.2 \%$ or majority of students stated that the instructional model of Jurisprudential Inquiry analysis of learning resources was taken from relevant mass media, print, electronic, and Indonesian textbooks. A total of $61.2 \%$ or majority of students stated that the Jurisprudential Inquiry analysis learning model felt actively involved in the learning process. A total of $62.2 \%$ or the majority of students stated that the Jurisprudential Inquiry analysis learning model is able to listen to opinions and appreciate others. A total of $70.4 \%$ or the majority of students stated that the Jurisprudential Inquiry analysis model of learning can foster critical thinking in determining decisions. A total of $67.3 \%$ or a large number of students stated that the Jurisprudential Inquiry analysis learning model became more critical of the news I read.

In group I, many students are not familiar with the application of Jurisprudential Inquiry analysis model because so far the first lecturers have first used the model, so the students are less ready when the implementation of Jurisprudential Inquiry analysis model.

The use of Jurisprudential Inquiry analysis model is based on behavior, academic ability and concept in learning. In this study using quantitative and qualitative methods. Based on the data obtained in this study, determined that there are significant positive differences in student learning concepts, overcome misunderstanding, academic achievement and understanding of the material that has been presented. This type of research is a classroom action research, the subject of this research is the first semester students in Introductory Course of Law Science. Data collection model is done through observation, test, documentation and interview. In this study, the task of observing researchers in teaching is the lecturer of the course. The results of this study indicate an increase in student learning outcomes. This research indicates that student learning outcomes before group I was implemented after group II using Jurisprudential Inquiry learning model of student learning outcomes increased and continued with group II student learning outcomes increased significantly. Overall, using Jurisprudential Inquiry analysis model case taken from print or online news can improve student learning outcomes.

The use of Jurisprudential Inquiry model analysis should be done considering the breadth of information should be sorted wisely without violating the norms and values applicable in social life, as the spread of fake online news has been identified as one of the major online abuse. Therefore, freedom of expression should stick to good ethics of communication and self-control $[14,15]$. The problem arising from the use of social media today is the large number of hoaxes that are widespread, even educated people can not distinguish what is true news, advertorial, and hoax $[8,14]$. Hoax or false news is the reality of the condition of chaos due to the diffusion of ICT. The goal is to earn profits from the number of people accessing the site and forwarding or linking through various other media distributed over a wider range [5,4]. This is because remembering how easy it is to create a website or social media page and monetize it through advertising. This has led to the proliferation of false news among various mass media in general [16].

The results of the study that Facebook's use in general do not support the profile so that users use the profile of others or falsify personal profile to become the ideal self [17]. In this case it is difficult to distinguish which is real and not, or it is difficult to clarify because information overlaps one another and it is difficult to get out of where the information begins. Authenticity becomes unclear. In different languages, technological realities or hoaxes are rampant so far can explain the implications of advanced capitalism in Jameson. Where the existing commodities in the form of hoaxes represent that virtual society of this era ignore the depth of information (depthlessness) and ahistoris [18].

Many kinds of false information sometimes bring the impact of difficult people to distinguish what kinds of fake barita circulating in the community. In general, the types of hoaxed information include fake news, clickbait, confirmation bias (confirmation bias), misinformation (satire information), satire (an article that uses humor, irony, exaggeration to comment on a warm event), post-truth (post-truth), and propaganda [8].

One of the earliest historical hoaxes lies in the "Great Lunar Month" of 1835, in which New York Sun published a series of articles on the discovery of life on the moon. Why with articles? For fake news articles have a lasting impact on a person even after being found wrong [16,19]. Even hoaxes exist that define as "false news" on news articles that are intentionally and can be proven wrong, and can mislead the readers and there are even more who call it "alternative facts" when the real facts of the news do not support the truth and broadcast to those who receive it $[16,20,21]$.

During this time, hoaxes were created and used as political weapons that are categorized into three namely: Source revealed, Anonymous sources, and false sources. Fake online news sources revealed are easily recognized and hidden behind freedom of speech. Anonymous sources of online fake news tend to be always covered in newsgroups or bulletin boards $[21,22]$. But nowadays, "fake news" is popularized in other related topics such as economics, psychology, political science, and computer science and even the medical world [16,23]. The fact that false news has jeopardized the confidence level of the news media in democracies relying heavily on news media to inform its citizens the mantra of problems for political decision-making among citizens and the political process [24]; [25]. Throughout history, hoaxes can really affect many people to tarnish the image and credibility of the victim. In addition, misinformation and misleading information has always been a deviation to human growth. Some hoaxes are created in a way that they can even obtain personal data by assuring the victims that the data is required for official purposes [26].

Therefore, the learning-oriented jurisprudential inquiry model that is oriented towards social interaction aimed at improving students by improving interpersonal relationships through democratic procedures philosophically models from this category assumes that education can develop individuals individually by reflecting ways of handling various information 
in concepts and values [27]. Therefore, education must be able to produce individual prospective citizens who are able to overcome the conflict of difference in various ways. This learning model makes the students to learn to think systematically about contemporary issues that are happening in society. By giving them ways of analyzing and discussing social issues to be sensitive to social problems, taking positions on those issues, and maintaining them with relevant and valid arguments [28].

\section{CONCLUSION}

Based on the results of research that has been achieved it can be concluded that: Learning Model Analysis Jurisprudential Inquiry as Prevention Efforts News Hoax in Students are arranged conceptually that has been formulated by researchers by involving materials, methods, sources and evaluation in overall lectures activities in realizing students who have critical thinking. Implementation of Learning Model Analysis Jurisprudential Inquiry as Prevention Efforts Hoax News in Students are directed to two main activities components, namely (1) lecturing activities, (2) extension activities. Both activities are arranged in the overall course activities of the students of the Department of Citizenship Education in the Introduction to Indonesian Law.

\section{REFERENCES}

[1] The Constitution of The Republic Indonesia 1945

[2] Law Number 9 of 1998 on Freedom of Expression in Public.

[3] M. William and O. Pearson, "Hate Crime and Bullying in the Age of Social Media-Conference Report," Cardiff University, England, 2016.

[4] S. Nasihin, "Desain Pendidikan Islalm Masa Depan: refleksi Pencarian Model Pendidikan Islam Ideal dalam Perspektif Filsafat Ilmu Keislaman (The Design of Islamic Education of The Future: The Reflection of The Search for the Ideal Islamic Educational Model in The Perspective of Islamic Philosophy)," At-Tajdid: Jurnal Ilmu Tarbiyah, vol. 6, no. 2, pp. 255-270, 2017.

[5] R. Istriyani and N.H. Widiana, Etika Komunikasi Islam dalam Membendung Informasi Hoax di Ranah Publik Maya (Ethics of Islamic Communication in Stemming Hoaxes in The Virtual Public Domain), 2016, pp. 288-315.

[6] S. Sidik, "Dampak Undang-Undang Informasi dan Transaksi Elektronik (UU ITE) terhadap Perubahan hukum dan Sosial dalam Masyarakat (impact of The Information and Electronic Transactions Act on Legal and Social Chang in Society)," Jurnal Ilmiah WIDYA, vol. 1, no. 1, pp.1-7, 2013.

[7] S.E. Nugroho, "Upaya Masyarakat Anti Fitnah Indonesia Mengembalikan Jatiiri Bangsa dengan Gerakan Anti Hoax (The Efforts of Anti-Slander Society of Indonesia to Restore The Identity of The Nation with Anti-Hoax Movement)," Prosiding Konferensi Nasional Peneliti Muda Psikologi Indonesia, vol. 2, no. 1, pp. 1-4, 2017.
[8] D.R. Rahadi, "Perilaku Pengguna dan Infromasi Hoax di Media Sosial (User Behavio and Hoax Information in Social Media)," Jurnal Manajemen dan Kewirausahaan, vol. 5, no. 1, pp. 58-70, 2017.

[9] M. Vukovi, K. Pripu, and H. Belani. "An Intelligent Automatic Hoax Detection System", in Proceedings of the 13th International Conference on Knowledge-Based and Intelligent Information and Engineering Systems: Part I. Springer-Verlag: Santiago, Chile. p. 318-325, 2009.

[10] C.J. Hernandez, J.M. Sierra, and A. Ribagorda, "A First Step towards Automatic Hoax Detection", in Proceedings. 36th Annual 2002 International Carnahan Conference on Security Technology, 2002.

[11] T. Petković, Z. Kostanjčar, and P. Pale, "E-Mail System for Automatic Hoax-Recognition", in XXVII, International Convention MIPRO 2005 Croatia, pp. 117-121, 2005.

[12] E. Blanzieri, and A. Bryl, "A Survey of Learning-based Techniques of Email Spam Filtering," Artif. Intell. Rev., vol. 29, no. 1, pp. 63-92, 2008.

[13] M. Wena, "Strategi Pembelajaran Inovatif Kotemporer (Innovative Cotemporary Learning Strategies), Jakarta: Bumi Aksara, 2009..

[14] F. Anwar, "Perubahan dan Permasalahan Media Sosial," Jurnal Muara Ilmu Sosial (Changes and Social Media Issues), Humaniora, dan Seni, vol. 1, no. 1, pp. 137-144, 2017.

[15] S.M. Sirajudeen, N.F.A. Azmi, A.I. Abubakar, "Online Fake News Detection Algorithm," Journal of Theoretical and Applied Information Technology, vol. 95, no. 17, pp. 4114-4122, 2017.

[16] H. Allcott and M. Gentzkow, Social Media and Fake News in the 2016 Election. Journal of Economic Perspectives, vol. 31, no. 2, pp. 211-236 2017.

[17] M.D. Back, "Facebook profiles reflect actual personality, not selfidealization," Psychological science, vol. 21, no. 3, pp. 372-374, 2010.

[18] F. Jameson, Posmodernism or The Cultural Logic of Late Capitalism.United States: Duke University Press, 1991.

[19] D. Polage, "Making up History: False Memories of Fake News Stories," Europe's Journal of Psychology, vol. 8, no. 2, pp. 245-250, 2012.

[20] G. Lee, "The importance of facts in this 'fake news' era," International Emergency Nursing, vol. 31, no. 1, pp. 1-1, 2017.

[21] H. Berghel, "Alt-News and Post-Truths in the" Fake News" Era." Computer, vol. 50, no. 4, pp. 110-114, 2017.

[22] H Berghel, "Lies, Damn Lies, and Fake News," Computer, vol. 50, no. 2, pp. 80-85, 2017.

[23] G.S. Tillotson, "Keeping the faith-reporting on antimicrobial resistance in an era of fake news". The Lancet Infectious Diseases, vol. 17, no. 5, pp. 473-474, 2017

[24] D. Jones, "Why Americans Don't Trust the Media," SAGE Journals, vol. 9, no. 2, pp. 60-75, 2004.

[25] M. Balmas, "When Fake News Becomes Real," SAGE Journals, vol. 41, no. 3, pp. 430-454, 2014.

[26] Y.Y. Chen, S.P. Yong, A. Ishak, "Email Hoax Detection System Using Levenshtein Distance Method," Journal of Computer, vol. 9, no. 2, pp. 441-446, 2014.

[27] AA. Wahab, Metode dalam Model-Model Mengajar (Methods in Teaching Models), Bandung: Alfa Beta, 2008.

[28] B.H. Uno, Model Pembelajaran (Menciptakan Proses Belajar Mengajar yang Kreatif dan Efektif) (Learning Models [Creating Creative and Effective Learning Process]), Jakarta: Bumi Aksara, 2009. 